\title{
PROFIL KOMPETENSI 4C'S SISWA DENGAN PEMBELAJARAN MODEL READING-CONCEPT MAP-JIGSAW PADA MATERI SISTEM EKSKRESI
}

\author{
Ari Ivayanti Ardik Sholikha', Wiwi Isnaeni \\ ${ }^{1,2}$ Universitas Negeri Semarang - Kampus Sekaran, Gunungpati, Semarang 50229
}

\begin{abstract}
Abstrak
Penelitian ini bertujuan untuk mengetahui pengaruh pembelajaran model reading-concept map-jigsaw pada materi sistem ekskresi terhadap kompetensi 4C's siswa SMA N 2 Ungaran. Penelitian ini adalah penelitian Quasi Experiment dengan desain penelitian Non-Equivalent Control Group Design. Populasi yang digunakan adalah seluruh kelas XI MIPA SMA N 2 Ungaran. Sampel yang digunakan adalah kelas XI MIPA 2 (32 siswa) sebagai kelas kontrol dan XI MIPA 3 (31 siswa) sebagai kelas eksperimen. Teknik pengambilan sampel menggunakan cluster random sampling. Ratarata nilai posttest kelas XI MIPA 2 adalah 80,76 dan kelas XI MIPA 3 adalah 90,21. Hasil uji independent sample $t$ test menunjukkan terdapat perbedaan rata-rata yang signifikan antara nilai posttest kelas eksperimen dan kontrol, dengan nilai signifikansi $0,000<0,05$. Uji $n$ gain dilakukan untuk mengetahui peningkatan keterampilan berpikir kritis siswa, yang menunjukkan hasil rata-rata $n$-gain kelas XI MIPA 2 adalah 0,64 (sedang) dan rata-rata $n$-gain XI MIPA 3 adalah 0,81 (tinggi). Rata-rata nilai kuesioner keterampilan berpikir kreatif pada kelas XI MIPA 2 adalah 70,73 dan kelas XI MIPA 3 adalah 75,21. Hasil uji independent sample $t$ test menunjukkan terdapat perbedaan rata-rata yang signifikan antara nilai kuesioner kelas eksperimen dan kontrol, dengan nilai signifikasi $0,008<0,05$. Rata-rata nilai observasi keterampilan komunikasi pada kelas XI MIPA 2 adalah 74,77 dan kelas XI MIPA 3 adalah 85,53. Rata-rata nilai observasi keterampilan kolaborasi pada kelas XI MIPA 2 adalah 77,03 dan kelas XI MIPA 3 adalah 83,88. Hasil uji independent sample $\mathrm{t}$ test menunjukkan terdapat perbedaan rata-rata yang signifikan antara hasil nilai observasi keterampilan komunikasi dan kolaborasi kelas eksperimen dan kontrol, dengan nilai signifikasi $0,000<0,05$. Hasil ini diperkuat dengan tanggapan guru dan siswa yang memberikan respon yang positif terhadap model pembelajaran remap jigsaw. Berdasarkan hasil penelitian disimpulkan pembelajaran model reading-concept mapjigsaw pada materi sistem ekskresi berpengaruh terhadap kompetensi 4C's siswa SMA N 2 Ungaran.
\end{abstract}

Kata kunci: kompetensi 4C's, model reading-concept map-jigsaw, sistem ekskresi. 


\section{PENDAHULUAN}

Abad 21 adalah abad yang menginginkan sumber daya manusia yang berkualitas. Pada abad ini diharapkan dunia pendidikan semakin meningkat, sehingga dihasilkan peserta didik yang memiliki keterampilan untuk berkembang di masa yang penuh dengan persaingan. Adapun keterampilan abad 21 meliputi 3 aspek yaitu keterampilan hidup dan berkarir, keterampilan belajar dan berinovasi, serta keterampilan teknologi dan media informasi (Trilling \& Fadel, 2009). Partnership for 21 st century skills menjelaskan bahwa terdapat keterampilan-keterampilan yang perlu dibekalkan kepada peserta didik. Diantara itu, aspek belajar dan berinovasi yang di dalamnya terdapat 4 keterampilan yang dikenal dengan "Four Cs" (4C's), yaitu Critical thinking (berpikir kritis), Creativity (kreativitas), Communication (komunikasi), dan Collaboration (kolaborasi) merupakan keterampilan yang harus dimiliki peserta didik di abad 21 ini.

Ada beberapa hal penting yang harus diperhatikan untuk mengembangkan pelajaran di abad 21 ini, diantaranya yaitu guru sebagai perencana pembelajaran, memasukkan unsur berpikir tingkat tinggi, dan penerapan pada pendekatan dan model pembelajaran yang bervariasi (Komara, 2018). Peran guru yang dapat dilakukan untuk mengembangkan keterampilan siswa yang dibutuhkan di abad 21 ini salah satunya yaitu dengan penerapan model pembelajaran.

Model Remap Coople kepanjangan dari Reading-Concept Mapping-Cooperative Learning. Pembelajaran model Remap Coople menurut Zubaidah (2014) adalah sebuah pembelajaran yang mengkombinasikan kegiatan membaca (reading), pembuatan peta konsep (concept mapping), dan pembelajaran menggunakan model kooperatif (cooperative learning). Kebiasaan membaca menjadi bagian penting dalam penguasaan dan pemahaman materi dalam peningkatan pengetahuan siswa. Pada penelitian Kohzadi et al. (2014) menjelaskan bahwa kegiatan membaca yang dilakukan secara terstruktur dapat mengembangkan keterampilan berpikir kritis yang dimiliki oleh setiap individu. Ada hubungan yang positif antara aktivitas membaca dan keterampilan berpikir kritis, dimana semakin sering siswa menghabiskan waktu untuk membaca, maka semakin besar keterampilan berpikir kritis mereka (Hawkins, 2012). Selain mengembangkan keterampilan berpikir kritis, menurut Wang (2012) menjelaskan bahwa kegiatan membaca yang dilakukan oleh siswa secara terstruktur dan terorganisir dapat 
mengembangkan keterampilan berpikir kreatifnya.

Kegiatan selanjutnya yaitu siswa ditugaskan untuk membuat peta konsep. Pembuatan peta konsep, selain dapat dilakukan setelah kegiatan membaca juga dapat dilakukan pada akhir pembelajaran. Menurut Novak \& Canas (2008) mendefinisikan peta konsep sebagai salah satu alat yang dapat digunakan untuk mempresentasikan pengetahuan yang digambarkan melalui konsep-konsep yang kemudian membentuk struktur hierarki yang bermakna. Pembuatan peta konsep dapat mengembangkan daya kreativitas yang dimiliki masing-masing peserta didik. Menurut Ramadhan et al. (2016) menjelaskan bahwa penyusunan peta kosep diharapkan dapat membantu siswa dalam mengorganisasikan sejumlah besar informasi terkait konsep pembelajaran.

Pembelajaran model kooperatif yang dipilih adalah tipe jigsaw. Menurut Rusman (2013) menjelaskan bahwa model kooperatif tipe jigsaw adalah model yang memfokuskan pada kerja kelompok yang dilakukan oleh siswa dalam bentuk kelompok kecil. Model kooperatif tipe jigsaw ini dicirikan dengan adanya kelompok asal dan kelompok ahli. Model kooperatif jigsaw ini membuat siswa memiliki tanggung jawab terhadap keberhasilan kelompoknya dan ketuntasan pada bagian materi yang sedang dipelajari.

Pembelajaran dengan model kooperatif tipe jigsaw dapat meningkatkan keterampilan sosial siswa, dalam hal bekerja sama dalam tim (berkolaborasi) dan berkomunikasi dengan baik kepada orang lain (Muthi'ah et al., 2018). Menurut Fadliyani et al. (2014) dan Susanto \& Susarno (2014) yang menyatakan bahwa pembelajaran tipe jigsaw ini dapat membuat siswa menjadi lebih aktif, dapat saling bekerja sama dengan baik dalam kelompok, saling menghargai, dan berkomunikasi dengan baik, serta mampu bersosialisasi dengan teman satu kelompok maupun satu kelas.

Berdasarkan hasil observasi di SMA Negeri 2 Ungaran pada bulan Agustus 2018 dan hasil wawancara dengan guru pengampu biologi, didapatkan informasi bahwa keterampilan berpikir siswa masih rendah. Hal ini ditandai dengan kurangnya kemampuan siswa untuk menganalisis permasalahan dan menghasilkan sebuah gagasan atau ide. Selain itu, kurangnya kemampuan siswa dalam menyampaikan pendapat saat proses pembelajaran dan kurangnya keterampilan siswa berbicara di depan kelas, sebagai indikasi keterampilan berkomunikasi siswa yang masih rendah. Proses diskusi 
yang yang telah berlangsung selama ini, ternyata masih ditemui beberapa permasalahan, seperti masih adanya beberapa siswa yang masih bergantung dengan anggota kelompoknya yang aktif dan seringkali belum ada pembagian tugas yang jelas pada saat anak bekerjasama dalam kelompoknya. Hal ini sebagai indikasi keterampilan kolaborasi dari siswa yang juga masih tergolong rendah. Materi sistem ekskresi menjadi salah satu materi yang dianggap sulit. Berdasarkan data persentase penguasaan materi soal biologi dalam Ujian Nasional SMA/MA tahun pelajaran 2016/2017, bahwa persentase penguasaan materi sistem ekskresi di SMA N 2 Ungaran tergolong rendah.

Salah satu alternatif untuk mengatasi permasalahan yang telah dipaparkan di atas adalah dengan menggunakan model pembelajaran Reading-Concept Map-Jigsaw (Remap Jigsaw) pada meteri sistem ekskresi. Beberapa penelitian yang relevan dengan penelitian ini dilakukan oleh Zubaidah et al. (2018) dalam penelitiannya menyimpulkan bahwa Remap Jigsaw telah meningkatkan minat baca dan keterampilan berpikir kritis siswa. Purwaningsih et al. (2017) dalam penelitiannya menyimpulkan bahwa model pembelajaran Remap NHT secara signifikan berpengaruh meningkatkan keterampilan berpikir kritis siswa. Penelitian Pangestuti (2017) dan Ramadhan et al. (2016) menyimpulkan bahwa model Remap STAD dapat meningkatkan keterampilan berpikir kritis siswa. Berdasarkan beberapa hasil penelitian terbukti bahwa model pembelajaran Reading Concept Map Cooperative Learning dengan beberapa tipe pembelajaran kooperatif berpotensi dalam meningkatkan keterampilan berpikir kritis siswa.

Selain itu, Menurut Tendrita et al. (2016) menyimpulkan bahwa keterampilan berpikir kreatif dapat dikembangkan melalui penerapan model pembelajaran, salah satunya adalah dengan menerapkan model pembelajaran Remap Coople. Penelitian oleh Mufida et al. (2017) menyimpulkan bahwa model pembelajaran Remap STAD berpengaruh terhadap keterampilan berpikir kreatif siswa.

Penelitian yang dilakukan oleh Indriwati et al. (2019) menyimpulkan bahwa model pembelajaran Remap Jigsaw dapat meningkatkan motivasi belajar dan keterampilan kolaboratif siswa. Penelitian oleh Anggis (2016) dan Halley et al. (2012) menyimpulkan bahwa pembelajaran tipe jigsaw dapat meningkatkan keterampilan kolaboratif pada siswa. Pada penelitian yang dilakukan oleh Susanto \& Susarno (2014), Fadliyani et al. (2014), dan Muthi'ah et al. (2018) menyimpulkan bahwa pembelajaran kooperatif jigsaw selain meningkatkan kemampuan kognitif siswa juga dapat 
meningkatkan keterampilan sosial siswa, diantaranya kerja sama antar siswa dalam tim (keterampilan berkolaborasi) dan keterampilan berkomunikasi siswa. Penelitian yang dilakukan oleh Halimah et al. (2019) menyimpulkan bahwa penerapan model pembelajaran kooperatif tipe jigsaw berhasil mengingkatkan keterampilan komunikasi verbal.

Berdasarkan permasalahan di atas, yang akan peneliti lakukan adalah melakukan penelitian Pengaruh Pembelajaran Model Reading-Concept Map-Jigsaw pada Materi Sistem Ekskresi terhadap Kompetensi 4C's Siswa SMA.

\section{METODE PENELITIAN}

Penelitian ini dilaksanakan pada semester genap tahun ajaran 2018/2019. Penelitian dilaksanakan di SMA N 2 Ungaran yang berlokasi di Jalan Diponegoro No. 277, Candirejo, Kec. Ungaran Barat, Kab. Semarang, Jawa Tengah 50512. Penelitian ini adalah penelitian Quasi Experiment dengan desain penelitian Non-Equivalent Control Group Design. Populasi yang digunakan pada penelitian ini adalah seluruh kelas XI MIPA SMA N 2 Ungaran yang terbagi ke dalam enam kelas MIPA. Sampel yang digunakan dalam penelitian ini adalah dua kelas XI MIPA. Kelas XI MIPA 3 (32 siswa) sebagai kelas eksperimen yang menggunakan model reading-concept map-jigsaw pada pembelajaran materi sistem ekskresi dan kelas XI MIPA 2 (31 siswa) yang dijadikan sebagai kelas kontrol yang menggunakan metode ceramah dan diskusi pada pembelajaran materi sistem ekskresi. Pengambilan sampel dilakukan menggunakan teknik cluster random sampling. Teknik pengumpulan data yang digunakan dalam penelitian ini meliputi tes, kuesioner (angket), observasi, wawancara, dan dokumentasi. Instrumen penelitian yang digunakan untuk mendapatkan data penelitian berupa lembar soal pretest dan posttest keterampilan berpikir kritis siswa, lembar kuesioner (angket) keterampilan berpikir kreatif siswa, lembar observasi komunikasi dan kolaborasi siswa, serta pedoman wawancara tanggapan guru dan siswa. Analisis kuantitatif digunakan untuk menganalisis tes keterampilan berpikir kritis, kuesioner keterampilan berpikir kreatif, dan lembar observasi keterampilan komunikasi dan kolaborasi. Sedangkan, analisis kualitatif digunakan untuk menganalisis hasil wawancara tanggapan guru dan siswa. Uji hipotesis menggunakan uji t-test dengan bantuan program aplikasi SPSS versi 20 setelah diuji normalitas dan homogenitas. 


\section{HASIL DAN PEMBAHASAN}

Adapun hasil penelitian, meliputi keterampilan berpikir kritis, keterampilan berpikir kreatif, keterampilan komunikasi, dan keterampilan kolaborasi siswa yang dibahas secara rinci sebagai berikut.

\section{Keterampilan Berpikir Kritis}

Penilaian keterampilan berpikir kritis siswa diperoleh dari nilai posttest. Nilai posttest dianalisis dengan menggunakan uji $t$-test. Syarat uji $t$-test terlebih dahulu data harus berdistribusi normal dan homogen. Analisis uji t-test menggunakan taraf signifikansi 5\% dilakukan dengan bantuan program aplikasi SPSS versi 20. Jenis uji $t$ test yang digunakan adalah uji independent sample t-test. Hasil uji independent sample t-test untuk nilai posttest keterampilan berpikir kritis dapat dilihat pada Tabel 1.

Tabel 1. Uji Independent Sample T Test untuk Posttest Keterampilan Berpikir Kritis

\begin{tabular}{lll}
\hline & XI MIPA 2 (Kontrol) & XI MIPA 3 (Eksperimen) \\
\hline Nilai Ideal & 100,00 & 100,00 \\
Nilai Minimal & 75,00 & 77,50 \\
Nilai Maksimal & 87,50 & 97,50 \\
Rata-rata & 80,76 & 90,21 \\
Jumlah Siswa & 36 & 36 \\
\hline
\end{tabular}

Sig. (2-tailed) $\quad 0,000$

Berdasarkan Tabel 1, hasil rata-rata posttest keterampilan berpikir kritis siswa kelas eksperimen yang memiliki rata-rata 90,21 lebih tinggi dibandingkan kelas kontrol yang memiliki rata-rata 80,76. Uji Independent Sample T Test menunjukikan jika nilai Sig. $<0,05(0,000<0,05)$, sehingga $H o$ ditolak. Dengan demikian, dapat disimpulkan bahwa terdapat perbedaan rata-rata yang signifikan antara hasil posttest keterampilan berpikir kritis siswa kelas eksperimen dan kelas kontrol.

Selain itu, untuk mengetahui peningkatan keterampilan berpikir kritis siswa, dilakukan perhitungan selisih antara nilai pretest dan posttest melalui uji normalized gain (n-gain). Melalui hasil rata-rata pretest di kelas eksperimen adalah 46,60 dan ratarata posttest adalah 90,21, sehingga kenaikan rata-rata hasil keterampilan berpikir kritis di kelas eksperimen sebesar 0,81 yang termasuk dalam kategori tinggi. Sedangkan, ratarata pretest kelas kontrol adalah 46,39 dan rata-rata posttest adalah 80,76 , sehingga kenaikan rata-rata hasil keterampilan berpikir kritis di kelas kontrol sebesar 0,64 yang 
termasuk dalam kategori sedang.

Dari hasil analisis yang telah dilakukan, terlihat bahwa terdapat perbedaan hasil keterampilan berpikir kritis antara kelas eksperimen dan kelas kontrol. Oleh karena itu, secara keseluruhan dapat dinyatakan bahwa pembelajaran model reading-concept mapjigsaw pada materi sistem ekskresi berpengaruh terhadap keterampilan berpikir kritis siswa SMA Negeri 2 Ungaran.

Begitupula dengan aspek-aspek keterampilan berpikir kritis menurut Ennis (2011) yang digunakan dalam penelitian ini, yang meliputi aspek (1) memberikan penjelasan sederhaan, (2) membangun keterampilan dasar, (3) menyimpulkan, (4) memberikan penjelasan lanjut, dan (5) mengatur strategi dan taktik, menunjukkan hasil persentase keterecapaian aspek tersebut, pada kelas eksperimen yang lebih tinggi daripada kelas kontrol.

Melalui pemilihan model pembelajaran yang tepat akan didapatkan hasil yang baik pula, dalam hal ini keterampilan berpikir kritis. Keterampilan berpikir kritis adalah proses berpikir secara logis untuk menentukan apa yang akan dilakukan (Ennis, 2011). Siswa yang menerapkan keterampilan berpikir kritisnya akan mampu untuk menganalisis suatu informasi, menafsirkan, mengevaluasi, dan meringkas (Trilling \& Fadel, 2009).

Pembelajaran model remap jigaw pada penelitian ini, memiliki langkah-langkah pembelajaran terdiri atas kegiatan membaca, kegiatan diskusi, dan pembuatan peta konsep. Kegiatan membaca dilakukan untuk menambah pengetahuan siswa, sehingga siswa mampu mengembangkan keterampilan berpikirnya. Hal ini sejalan dengan yang disampaikan oleh Rosyida et al. (2016) yang menjelaskan bahwa kegiatan membaca membuat siswa mempunyai lebih banyak informasi yang nantinya digunakan sebagai landasan berpikir dalam memutuskan suatu kesimpulan dari konsep materi yang dipelajari. Ditambahkan oleh Ratnawati et al. (2015) yang menjelaskan bahwa kegiatan membaca yang dilakukan oleh siswa merupakan sarana dalam menambah wawasan dan pengetahuan siswa sehingga dapat merangsang otak siswa untuk berpikir.

Kegiatan membaca yang dilakukan oleh siswa ini dapat membantu mengembangkan keterampilan berpikir kritis siwa. Hal ini sebagaimana yang disampaikan oleh Karadeniz (2015) yang menyatakan bahwa membaca menjadi sebuah kegiatan yang efektif karena dengan membaca peserta didik dapat meningkatkan diri 
mereka sendiri mengenai pemikiran yang kritis. Ditambahkan oleh Aloqaili (2011) dan Hosseini et al. (2012) yang juga menyatakan bahwa terdapat hubungan antara aktivitas membaca dengan kemampuan berpikir kritis siswa.

Setelah kegiatan membaca, proses pembelajaran dilanjutkan dengan melakukan diskusi model kooperatif tipe jigsaw. Hasil wawancara dengan siswa, didapatkan informasi bahwa salah satu peningkatan dalam diri yang mereka rasakan setelah melakukan pembelajaran yaitu mereka terdorong untuk menjadi pribadi yang memahami dan menguasai materi yang sedang dipelajari dengan lebih lengkap, untuk nantinya dapat mereka jelaskan ke teman-teman kelompoknya. Sebagaimana disampaikan oleh Mitasari \& Prasetiyo (2016) yang menyampaikan bahwa tujuan berpikir kritis adalah untuk mencapai sebuah pemahaman yang mendalam pada diri seseorang.

Penelitian yang dilakukan oleh Anggis (2016) menyatakan bahwa pembelajaran kooperatif tipe jigsaw dapat mendorong siswa untuk berkontribusi dalam memberikan berbagai macam ide, sehingga dapat menstimulasi otak untuk berpikir. Ditambahkan oleh Ramadhan et al. (2016) yang menyampaikan bahwa proses diskusi secara berkelompok dapat membuat siswa terlatih dalam berpikir kritis. Hal ini karena saat diskusi, masing-masing dari anggota kelompok bebas mengutarakan ide-ide mereka. Dengan ide-ide yang dikeluarkan ini, membuat siswa untuk terus berpikir untuk menemukan formasi jawaban yang utuh untuk menjawab pertanyaan yang disediakan.

Diskusi yang dilakukan, baik dalam kelompok ahli maupun kelompok asal akan membuat siswa berkembang daya pikirnya sehingga dapat menyelesaikan permasalahan yang disedikan ketika berlangsungnya kegiatan diskusi kelompok. Hal ini sejalan dengan penelitian yang dilakukan Hertiavi et al. (2010), yang menjelaskan bahwa pembelajaran dengan menggunakan model kooperatif tipe jigsaw dapat meningkatkan kemampuan siswa dalam memecahkan permasalahan yang ada.

Setelah, kegiatan diskusi dilanjutkan dengan pembuatan peta konsep oleh masing-masing kelompok. Pembuatan peta konsep juga sebagai pendukung siswa untuk mengembangkan keterampilan berpikirnya. Hal ini sejalan dengan penelitian yang dilakukan oleh Khodadady \& Ghanizadeh (2011) menyimpulkan bahwa peta konsep berpengaruh secara signifikan terhadap keterampilan berpikir kritis. 


\section{Keterampilan Berpikir Kreatif}

Hasil keterampilan berpikir kreatif diperoleh melalui nilai kuesioner keterampilan berpikir kreatif siswa. Hasil uji independent sample t-test nilai keterampilan berpikir kreatif dapat dilihat pada Tabel 2.

Tabel 2. Uji Independent Sample T Test Nilai Keterampilan Berpikir Kreatif

\begin{tabular}{lll}
\hline & XI MIPA 2 (Kontrol) & XI MIPA 3 (Eksperimen) \\
\hline Nilai Ideal & 100,00 & 100,00 \\
Nilai Minimal & 61,25 & 63,75 \\
Nilai Maksimal & 85,00 & 98,75 \\
Rata-rata & 70,73 & 75,21 \\
Jumlah Siswa & 36 & 36 \\
\hline Sig. (2-tailed) & 0,008 & \\
\hline
\end{tabular}

Berdasarkan Tabel 2, hasil rata-rata kuesioner keterampilan berpikir kreatif siswa, kelas eksperimen yang memiliki rata-rata 75,21 lebih tinggi dibandingkan kelas kontrol yang memiliki rata-rata 70,73. Uji Independent Sample T Test menunjukkan jika nilai Sig. $0,05(0,008<0,05)$, sehingga $H 0$ ditolak. Dengan demikian, dapat disimpulkan bahwa terdapat perbedaan rata-rata yang signifikan antara hasil nilai kuesioner keterampilan berpikir kreatif kelas eksperimen dan kelas kontrol. Oleh karena itu, dapat dinyatakan bahwa pembelajaran model reading-concept map-jigsaw pada materi sistem ekskresi berpengaruh terhadap keterampilan berpikir kreatif siswa SMA Negeri 2 Ungaran.

Pembelajaran model remap jigsaw diawali dengan kegiatan membaca, yang digunakan untuk mengembangkan keterampilan berpikirnya. Hal ini sejalan dengan yang disampaikan oleh Wang (2012) yang menyatakan bahwa kegiatan membaca yang dilakukan oleh siswa secara terstruktur dapat mengembangkan keterampilan berpikir kreatifnya. Pada penelitian ini, kegiatan membaca dilakukan di rumah. Ditambah, sebelum memasuki pembelajaran, siswa diberikan waktu untuk mengulang lagi kegiatan membaca yang telah mereka lakukan. Intensitas membaca yang lebih banyak dari biasanya ini, membuat siswa akan mampu mengembangkan keterampilan berpikirnya. Hal ini sejalan seperti yang disampaikan oleh Tendrita et al. (2016) yang menyampaikan bahwa bagi siswa yang mempergunakan waktunya lebih banyak untuk membaca secara tidak langsung dapat meningkatkan keterampilan berpikir kreatifnya, diantaranya mereka mampu untuk mengembangkan sebuah ide dan gagasan untuk menyelesaikan suatu permasalahan.

Keterampilan berpikir kreatif siswa, terlihat ketika proses pembelajaran, 
diantaranya ketika siswa mengajukan pertanyaan apabila ada bagian yang belum dimengerti, berusaha menjawab pertanyaan yang datang kepadanya, ketika siswa memberikan pendapat saat proses diskusi, ketika siswa mengajukan gagasan baru dalam menyelesaikan suatu permasalahan dengan cara yang lebih mudah dipahami, serta ketika siswa mampu menghasilkan produk berupa peta konsep yang mereka buat secara berkelompok. Hal ini sesuai dengan yang disampaikan oleh Insyasiska et al. (2015) bahwa dalam proses pembelajaran, keterampilan berpikir kreatif ini dapat berupa gagasan, pendapat, ide-ide yang diberikan oleh siswa. Selain itu, hasil kreativitas ini juga dapat berupa produk yang dibuat oleh siswa, baik itu dalam bentuk laporan tertulis, slide powerpoint, dan media gambar.

Keterampilan berpikir kreatif merupakan keterampilan individu menggunakan proses berpikirnya untuk menghasilkan gagasan (ide) yang baru berdasarkan konsepkonsep yang rasional. Keterampilan berpikir kreatif dibangun berdasarkan konsep yang telah tertanam dalam pikirannya yang kemudian konsep tersebut diaplikasikan untuk individu itu menyelesaikan permasalahan (Handoko, 2018).

Aspek-aspek keterampilan berpikir kreatif yang digunakan dalam penelitian ini berdasarkan aspek-aspek yang dikembangkan oleh Munandar (dalam Handoko, 2018) yang meliputi (1) berpikir lancar, (2) berpikir luwes, (3) berpikir asli, dan (4) berpikir terperinci, yang menunjukkan hasil persentase keterecapaian aspek tersebut pada kelas eksperimen yang lebih tinggi daripada kelas kontrol. Aspek keterampilan berpikir kreatif yang pertama adalah berpikir lancar yang menunjukkan persentase hasil pada kelas eksperimen yang lebih tinggi dari pada kelas kontrol yaitu $75,17 \%$, sedangkan pada kelas kontrol yaitu 71,82\%. Aspek keterampilan berpikir kreatif yang kedua adalah berpikir luwes, dengan persentase hasil pada kelas eksperimen yang lebih tinggi dari pada kelas kontrol yaitu 71,18\%, sedangkan pada kelas kontrol yaitu 67,71\%.

Aspek keterampilan berpikir kreatif yang ketiga adalah berpikir asli yang menunjukkan persentase hasil pada kelas eksperimen yang lebih tinggi dari pada kelas kontrol yaitu 68,21\%, sedangkan pada kelas kontrol yaitu 67,90\%. Aspek keterampilan berpikir kreatif yang keempat adalah berpikir terperinci, dengan persentase hasil pada kelas eksperimen yang lebih tinggi dari pada kelas kontrol yaitu 81,08\%, sedangkan pada kelas kontrol yaitu 75,00\%.

Pembuatan peta konsep oleh siswa dapat meningkatkan kemampuan dalam 
memahami, berpikir, dan kreativitas siswa. Dalam penelitian yang dilakukan oleh Pranyandari et al. (2014) menunjukkan bahwa, proses pembelajaran berbasis peta konsep dapat meningkatkan hasil belajar dari siswa.

\section{Keterampilan Komunikasi Siswa}

Penilaian keterampilan komunikasi siswa diperoleh dari hasil nilai observasi. Hasil uji independent sample t-test untuk nilai keterampilan komunikasi dapat dilihat pada Tabel 3.

Tabel 3. Uji Independent Sample T Test Nilai Keterampilan Komunikasi

\begin{tabular}{lll}
\hline & XI MIPA 2 (Kontrol) & XI MIPA 3 (Eksperimen) \\
\hline Nilai Ideal & 100,00 & 100,00 \\
Nilai Minimal & 58,33 & 70,83 \\
Nilai Maksimal & 87,50 & 95,83 \\
Rata-rata & 74,77 & 85,53 \\
Jumlah Siswa & 36 & 36 \\
\hline Sig. (2-tailed) & 0,000 & \\
\hline \multicolumn{1}{c}{ Berdasarkan } & Tabel & 3, hasil rata-rata keterampilan komunikasi siswa kelas
\end{tabular}

eksperimen yang memiliki rata-rata 85,53 lebih tinggi dibandingkan kelas kontrol yang memiliki rata-rata 74,77. Uji Independent Sample T Test menunjukikan jika nilai Sig.< $0,05(0,000<0,05)$, sehingga $H o$ ditolak. Dengan demikian, dapat disimpulkan bahwa terdapat perbedaan rata-rata yang signifikan antara hasil nilai observasi keterampilan komunikasi kelas eksperimen dan kelas kontrol. Oleh karena itu, dapat dinyatakan bahwa pembelajaran model reading-concept map-jigsaw pada materi sistem ekskresi berpengaruh terhadap keterampilan komunikasi siswa SMA Negeri 2 Ungaran.

Salah satu langkah pembelajaran model remap jigsaw adalah proses diskusi yang menggunakan model kooperatif tipe jigsaw. Ketika siswa berada dalam kelompok diskusi, siswa diberikan kesempatan untuk berinteraksi secara aktif dan positif dalam kelompok belajarnya. Hal ini sesuai sebagaimana yang disampaikan oleh Muthi'ah et al. (2018) yang menjelaskan bahwa diskusi tipe jigsaw ini membuat siswa dapat berkomunikasi dengan baik dengan teman sesama kelompoknya.

Keterampilan komunikasi siswa, selain ditunjukkan ketika proses diskusi, juga ditunjukkan pada saat siswa melakukan presentasi. Dalam penelitian ini, setelah berlangsungnya proses diskusi oleh siswa. Kegiatan selanjutnya adalah pembuatan peta konsep yang kemudian dilanjutkan dengan mempresentasikan hasil peta konsep yang dibuat oleh masing-masing kelompok ke depan kelas. Kegiatan ini, dilakukan untuk 
mengembangkan keterampilan komunikasi siswa. Sebagaimana yang disampaikan oleh Grace \& Gilsdorf (2004) yang menyatakan bahwa keterampilan komunikasi dapat ditingkatkan melalui kegiatan praktik, seperti keterampilan komunikasi lisan dapat ditingkatkan melalui kegiatan presentasi di depan kelas.

Ditambahkan oleh Faizah et al. (2013) yang menjelaskan bahwa terdapat keterampilan yang perlu untuk dikembangkan pada diri sesorang yang menjadi bekal bagi seseorang di kehidupan mendatang, seperti keterampilan komunikasi yang dilatih melalui kegiatan berbagai presentasi. Menururt Hernawati \& Amin (2017) dan Purwatiningsih (2009) menjelaskan bahwa presentasi adalah sebuah bentuk proses komunikasi lisan yang dilakukan secara terpadu, baik melalui suara, gambar, dan bahasa tubuh.

Presentasi yang dilakukan oleh siswa, juga diamati kesesuaiannya berdasarkan enam indikator keterampilan komunikasi lisan yang digunakan pada penelitian ini yang mengacu pada indikator yang dikembangkan oleh Universitas Baltimore. Hasil penelitian menunjukkan bahwa, indikator-indikator keterampilan komunikasi yang meliputi (1) mengorganisasi informasi, (2) menjaga kontak mata, (3) menyampaikan dengan komunikatif, (4) mampu menyimpulkan, (5) mampu merespons dan mengatur waktu, dan (6) memanfaatkan bantuan media, menunjukkan persentase ketercapaian pada kelas eksperimen lebih tinggi daripada kelas kontrol.

Indikator yang pertama adalah mengorganisasi informasi. Pada indikator mengorganisasi informasi, didapatkan hasil untuk persentase ketercapaian indikator ini, pada kelas eksperimen lebih tinggi daripada kelas kontrol yaitu 92,36\%, sedangkan pada kelas kontrol yaitu $86,11 \%$. Kelas eksperimen lebih menguasai materi yang disampaikannya dan mencoba untuk menjelaskan secara runtut dan lengkap kepada audiens. Hal ini sebagaimana yang disampaikan oleh Sukaedi (2016) yang menyatakan bahwa salah satu kelebihan proses presentasi adalah presentator dapat menjelaskan informasi terkait seluruh materi yang dipresentasikan secara sistematis atau terorganisasi.

Indikator keterampilan komunikasi yang kedua adalah menjaga kontak mata. Hasil persentase ketercapaian indikator ini, menunjukkan bahwa kelas eksperimen lebih tinggi daripada kelas kontrol yaitu 78,47\%, sedangkan pada kelas kontrol yaitu 69,44\%. Hal ini karena, kelas eksperimen lebih banyak terlibat secara aktif dalam memperoleh 
informasi terkait materi yang sedang dipelajari. Oleh karena itu, ketika proses presentasi, siswa kelas eksperimen mengurangi intensitas dalam melihat catatan mereka, karena mereka telah memperoleh pengalaman saat proses pembelajaran berlangsung.

Begitu pula dengan indikator yang ketiga yaitu menyampaikan dengan komunikatif, yang menunjukkan persetase ketercapaian indikator ini di kelas eksperimen yang lebih tinggi daripada kelas kontrol yaitu 91,67\%, sedangkan pada kelas kontrol yaitu 79,17\%. Wawancara pada siswa, didapatkan informasi bahwa ketika pelaksanaan presentasi, mereka lebih percaya diri dan mengetahui kekurangan mereka, yang semula presentasinya suaranya kecil dan kurang jelas kemudian dapat mereka perbaiki. Sebagaimana menurut Faizah et al. (2013) yang menjelaskan bahwa rasa percaya diri dalam hal berkomunikasi merupakan salah satu soft skill yang perlu dikembangkan pada diri setiap orang, karena dengan adanya soft skill percaya diri ini sangat menunjang kesuksesan seseorang dalam dunia pekerjaan atau dimanapun mereka berada.

Indikator keterampilan komunikasi yang keempat yaitu mampu menyimpulkan. Hasil persentase ketercapian indikator ini, pada kelas eksperimen lebih tinggi daripada kelas kontrol yaitu 75,00\%, sedangkan pada kelas kontrol yaitu 65,97\%. Setelah melakukan presentasi, beberapa siswa di kelas eksperimen telah berusaha menambahkan informasi tambahan yang mereka dapatkan ketika proses diskusi yang terlewatkan atau belum disampaiakan oleh kelompok sebelumnya.

Indikator keterampilan komunikasi yang kelima yaitu mampu merespons dan mengatur waktu. Hasil persentase indikator ini menunjukkan kelas eksperimen lebih tinggi daripada kelas kontrol yaitu 79,86\%, sedangkan kelas kontrol yaitu 72,92\%. Proses presentasi yang dilakukan memunculkan respon siswa untuk memberikan pertanyaan atas apa yang dipresentasikan oleh kelompok yang sedang maju di depan kelas. Hal ini sejalan dengan penelitian yang dilakukan oleh Mustikawati et al. (2018) yang menyatakan bahwa kegiatan diskusi dan presentasi yang dilakukan oleh siswa membuat siswa belajar untuk saling berkomunikasi dalam hal pekerjaan mereka serta menanyakan dan menjawab pertanyaan yang datang dari teman dan guru, sehingga akan memunculkan ide-ide baru pikiran siswa

Indikator keterampilan komunikasi yang keenam adalah memanfaatkan bantuan media. Hasil persentase ketercapaian indikator ini menunjukkan kelas eksperimen 
mendapatkan hasil yang lebih tinggi daripada kelas kontrol yaitu 95,83\%, sedangkan pada kelas kontrol yaitu 75,00\%. Bantuan media yang digunakan oleh kelas eksperimen berupa peta konsep yang telah dibuat bersama-sama secara berkelompok dan dibuat sesuai kreativitas masing-masing kelompok. Sedangkan, untuk kelas kontrol, presentasi dilakukan dengan menggunakan powerpoint yang juga dibuat oleh masing-masing kelompok. Powerpoint yang telah dibuat masih terlihat beberapa kekurangan. Dimana yang terjadi adalah isi powerpoint yang disajikan oleh kelompok penyaji saat proses presentasi bukan menulis poin-poin penting dari materi yang akan disampaikan, akan tetapi masih penuh dengan tulisan.

\section{Keterampilan Kolaborasi Siswa}

Penilaian keterampilan kolaborasi siswa diperoleh dari hasil nilai observasi. Hasil uji independent sample t-test untuk nilai keterampilan kolaborasi dapat dilihat pada Tabel 4.

Tabel 4. Uji Independent Sample T Test Nilai Keterampilan Kolaborasi

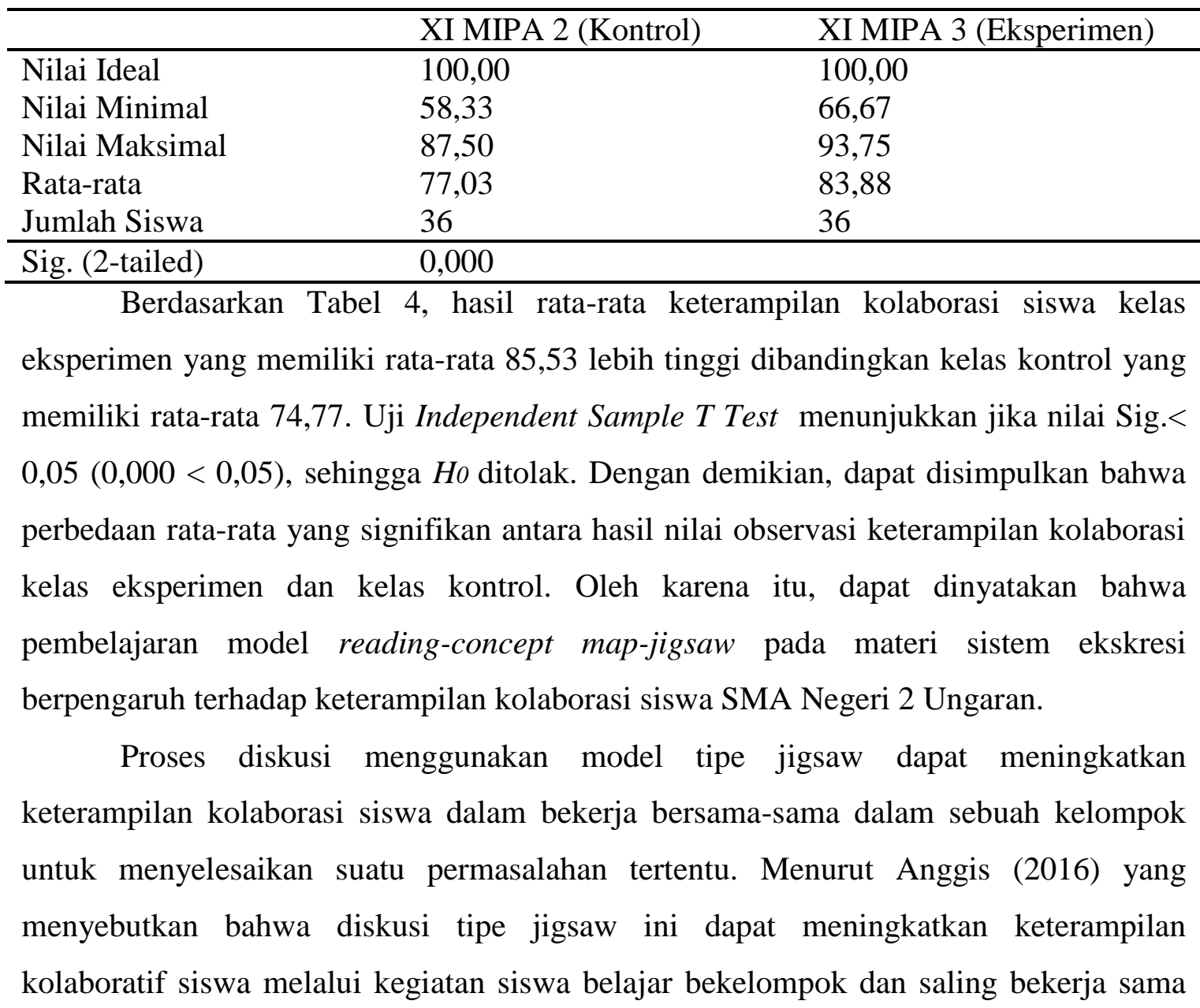


dalam mengerjakan tugas yang diberikan. Serta, hal ini diperkuat dengan penelitian yang dilakukan oleh Indriwati et al. (2019) yang menyimpulkan bahwa model pembelajaran reading concept mapping jigsaw dapat meningkatkan motivasi belajar dan keterampilan kolaboratif siswa.

Kolaborasi menurut Partnership for 21 st Century Skill yang dimuat dalam NEA, bahwa kolaborasi adalah kemampuan untuk bekerja secara efektif dan menghormati pendapat kelompok yang beragam. Selain itu, melatih kemauan untuk membuat keputusan diskusi bersama untuk mencapai tujuan tujuan yang diharapkan, serta memiliki tanggung jawab dan kontribusi dalam kelompok. Hasil penelitian menunjukkan persentase ketercapaian untuk enam indikator keterampilan kolaborasi kelas eksperimen lebih tinggi daripada kelas kontrol. Indikator-indikator keterampilan kolaborasi yang digunakan pada penelitian ini mengacu pada indikator yang dikembangkan oleh Hermawan et al. (2017) yang mengadaptasi dari aspek keterampilan kolaborasi menurut International Reading Association (IRA) yang meliputi (1) berkontribusi, (2) mampu mengatur waktu, (3) memecahkan masalah, (4) bekerja dengan orang lain, (5) menguasai teknik penyelidikan, dan (6) mensintesis.

Indikator keterampilan kolaborasi yang pertama yaitu berkontribusi. Hasil persentase ketercapaian indikator tersebut pada kelas eksperimen lebih tinggi daripada kelas kontrol yaitu 89,24\%, sedangkan pada kelas kontrol adalah 79,86\%. Hasil wawancara dengan siswa didapatkan informasi bahwa mereka sudah berpartisipasi secara aktif dalam pembelajaran. Partisipasi yang dilakukan oleh mereka lebih baik dibanding pembelajaran biasanya. Hal ini sejalan dengan yang disampaikan oleh Karacop \& Diken (2017) yang menyatakan bahwa pembelajaran kooperatif tipe jigsaw mendorong partisipasi siswa di kelas.

Pembelajaran pada kelas eksperimen yang menggunakan model remap jigsaw, yang mana masing-masing anggota memiliki tanggungjawab yang harus mereka kerjakan. Sehingga hal inilah yang dapat meminimalisir adanya siswa yang hanya menggantungkan diri pada anggota kelompoknya yang lain. Hal ini sejalan dengan penelitian yang dilakukan oleh Indriwati et al. (2019) yang menyatakan bahwa pembelajaran model remap jigsaw dapat mengembangkan keterampilan kolaboratif siswa, salah satunya adalah ketika dalam penyelesaian tugas para siswa melakukan pembagian tugas sehingga dapat meneylesaikan tugas tersebut dengan baik. 
Indikator keterampilan kolaborasi yang kedua adalah mampu mengatur waktu. Namun, hasil persentase ketercapaian indikator ini menunjukkan kedua kelas mendapat hasil yang sama yaitu $75,00 \%$. Hal ini disebabkan karena kedua kelas belum bisa tepat waktu sesuai waktu yang telah ditetapkan saat proses diskusi berlangsung, sehingga menyebabkan mereka memperpanjang batas waktu kira-kira 1 sampai 5 menit. Hasil wawancara dengan guru biologi didapatkan masukan bahwa untuk memperbaiki proses pembelajaran model remap jigsaw ini yaitu dengan bisa mengatur waktu secara lebih baik lagi, terlebih pada model ini menggunakan beberapa kelompok diskusi. Jadi, dengan pengaturan waktu yang baik dapat terciptanya pembelajaran yang diharapkan.

Indikator keterampilan kolaborasi yang ketiga adalah memecahkan masalah. Hasil persentase pada kelas eksperimen menunjukkan hasil lebih tinggi daripada kelas kontrol yaitu 82,47\%, sedangkan kelas kontrol yaitu 78,13\%.. Indikator keterampilan kolaborasi yang keempat adalah bekerja dengan orang lain. Hasil persentase ketercapaian indikator ini, menunjukkan bahwa kelas eksperimen mendapatkan hasil lebih tinggi daripada kelas kontrol yaitu 92,36\%, sedangkan pada kelas kontrol yaitu $81,60 \%$.

Interaksi yang baik antar sesama anggota kelompok ini membuat siswa akan saling bekerjasama, saling memiliki ketergantungan positif untuk saling membantu antar sesama anggota kelompok, dan melatih tanggungjawab siswa sehingga tercapainya tujuan bersama dalam kelompok. Hal tersebut sesuai dengan yang disampaikan oleh Nurnawati et al. (2012) dan Suratno (2010) yang menyampaikan bahwa pada pembelajaran model kooperatif tipe jigsaw, salah satu tujuannya yaitu untuk mengembangkan keterampilan sosial siswa, yang salah satu aspek yang ada di dalamnya adalah kerjasama. Intensitas kerjasama yang tinggi dilakukan siswa dalam kelompok timnya. Kerjasama antar siswa dalam kelompok ini terjalin baik dalam hal penyelesaian tugas. Sebagaimana juga yang disampaiakan oleh Muthi'ah et al. (2018) yang menjelaskan bahwa saat siswa sedang melakukan diskusi tipe jigsaw, siswa dapat melatih dirinya untuk mampu bekerjasama dengan teman lainnya, saling memiliki ketergantungan positif satu dengan yang lainnya, dan mampu melatih tanggungjawab pada diri siswa untuk menyelesaikan tugas yang didapatkannya.

Indikator keterampilan kolaborasi yang kelima adalah menguasai teknik penyelidikan. Persentase ketercapaian indikator ini menunjukkan bahwa kelas 
eksperimen mendapat hasil yang lebih tinggi daripada kelas kontrol yaitu 84,90\%, sedangkan pada kelas kontrol yaitu $75,00 \%$. Indikator keterampilan kolaborasi yang keenam adalah mensintesis. Persentase pada indikator ini menunjukkan bahwa hasil kelas eksperimen lebih tinggi daripada kelas kontrol yaitu 79,34\%, sedangkan pada kelas kontrol yaitu 72,57\%.

Dari hasil wawancara dengan siswa, sebagian besar siswa menyatakan bahwa pembelajaran dengan model remap jigsaw membuat siswa semakin dekat dengan temannya. Hal ini sejalan dengan Fitri et al. (2018) yang menyatakan bahwa kegiatan kolaboratif membuat siswa dapat mengenal satu sama lain dan sesuai apabila diterapkan pada sekolah yang siswanya berasal dari latar belakang yang berbeda. Sebagaimana juga yang disampaikan oleh Muthi'ah et al. (2018) yang menjelaskan bahwa diskusi tipe jigsaw ini membuat siswa mampu bersosialisasi dengan temannya, baik itu teman satu kelompoknya maupun teman satu kelasnya. Blaney et al. (1977) dalam Slavin (2010:135) meyatakan bahwa pembelajaran jigsaw yang merupakan tipe pembelajaran kooperatif dapat berpengaruh terhadap hubungan antar sesama siswa secara positif.

\section{SIMPULAN}

Berdasarkan hasil penelitian dapat disimpulkan bahwa pembelajaran model reading-concept map-jigsaw pada materi sistem ekskresi berpengaruh secara signifikan terhadap kompetensi 4C's (Critical thinking, Creativity, Communication, and Collaboration Skills) siswa SMA Negeri 2 Ungaran. 


\section{DAFTAR PUSTAKA}

Aloqaili, A. S. 2011. The Relationship Between Reading Comprehension and Critical Thinking: A Theoretical Study. Journal of King Saud University-Languages and Translation, 24: 35-41.

Anggis, Eka Vasia. 2016. Peran Model kooperatif Jigsaw Berbasis Lesson Study untuk Meningkatkan Keterampilan Kolaboratif dan Hasil Belajar Kognitif. Proceeding Biology Education Conference, 13(1): 493-497.

Ennis, RH. 2011. The Nature of Critical Thinking: An Outline of Critical Thinking Dispositions and Abilities. New Jersey: University of Illinois.

Fadliyani, Muhibbuddin, dan M. A. Sarong. 2014. Pembelajaran Kooperatif Tipe Jigsaw pada Konsep Sistem Pencernaan Makanan Manusia Terhadap Hasil Belajar Siswa SMA Negeri 1 Sakti Kabupaten Pidie. Jurnal Biotik, 2 (1): 17-22.

Faizah, S. S. Miswadi, S. Haryani. 2013. Pengembangan Perangkat Pembelajaran Berbasis Masalah untuk Meningkatkan Soft Skill dan Pemahaman Konsep. Jurnal Pendidikan IPA Indonesia, 2(2): 120-128.

Fitri, F. A., Y. U. Anggraito, S. Alimah. 2018. The Effectiveness of Guided Inquiry Strategy on Students'Collaborative Skill. Journal of Biology Education, 7(2): 144-150.

Grace, D. M. \& J. W. Gilsdorf 2004. Classroom Strategies for Improving Students'Oral Communication Skills. Journal of Accounting Education. Ed. 22. pp:165-172.

Halimah, L. \& V. Sukmayadi. 2019. The Role of "Jigsaw" Method in Enchancing Indonesian Prospective Teachers'Pedagogical Knowledge and Communication Skill. International Journal of Instruction, 12(2): 289-304.

Halley, J., C. Heiserman, V. Felix, A. Eshleman. 2013. Students Teaching Students: A Method for Collaborative Learning. Learning Communities Research and Practice, Vol. 1, Iss. 3, Art.7. pp: 1-18.

Handoko, Hendri. 2018. Pembentukan Keterampilan Berpikir Kreatif pada Pembelajaran Matematika Model SAVI Berbasis Discovery Learning Strategy Materi Dimensi Tiga Kelas X. Jurnal EduMa, 6(1): 85-95.

Hawkins, K. T. 2012. Thinking and Reading Among College Undergraduates: An Examination of the Relationship Between Critical Thinking Skills and Voluntary Reading. Dissertation. University of Tennessee.

Hermawan, P Siahaan, E Suhendi, I Kaniawati, A Samsudin, A. H. Setyadin, S. R. Hidayat. 2017. Desain Rubrik Kemampuan Berkolaborasi Siswa SMP dalam Materi Pemantulan Cahaya. JPPPF-Jurnal Penelitian\&Pengembangan Pendidikan Fisika, 3(2): 167-174.

Hernawati, D. \& M. Amin. 2017. Analisis Self Efficacy Mahasiswa Melalui Kemampuan Presentasi di Kelas. Education and Human Development Journal, 02 (01): 26-33.

Hertiavi, M. A., L Langlang, S Khanafiyah. 2010. Penerapan Model Pembelajaran Kooperatif Tipe Jigsaw untuk Peningkatan Kemampuan Pemecahan Masalah Siswa SMP. Jurnal Pendidikan Fisika Indonesia. Vol 6: 53-57.

Hosseini, E., F. B. Khodaei, S. Sarfallah, H. R. Dolatabadi. 2012. Exploring the Relationship Between Critical Thinking, Reading Comprehension, and Reading Strategies of English University Students. World Applied Sciences Journal, 17(10): 1356-1364.

Indriwati, S. E., H. Susilo, I. M. S. Hermawan. 2019. Improving Students' Motivation and Collaborative Skills Through Remap Jigsaw Learning Combined with 
Modelling Activities. Jurnal Pendidikan Biologi Indonesia, 5(2): 177-184. Insyasiska, D., S Zubaidah, H Susilo. 2015. Pengaruh Project Based Learning Terhadap Motivasi Belajar, Kreativitas, Kemampuan Berpikir Kritis, dan Kemampuan Kognitif Siswa pada Pembelajaran Biologi. Jurnal Pendidikan Biologi, 7(1): 921.

Karacop, A. \& E. H. Diken. 2017. The Effect of Jigsaw Technique Based on Cooperative Learning on Prospective Science Teachers' Science Process Skill. Journal of Education and Practice, 8(6): 86-97.

Karadeniz, Abdulkerim. 2015. An Examination of Critical Reading Self-efficacy Perceptions Among the Students of the Faculty of Education Over Different Variables. Anthropologist, 22(2): 167-175.

Khodadady, E \& Ghanizaedah, A. 2011. The Impact of Concept Mapping on EFL Learners'Critical Thinking Ability. English Language, 9: 77-84.

Kohzadi, H., F. Azizmohammadi, F. Samadi. 2014. Is There A Relationship Between Critical Thinking and Critical Reading Of Literary Text: A Case Study at Arak University (Iran). International Letters of Social and Humanistic Science. Vol 33. Page: $63-76$.

Komara, Endang. 2018. Penguatan Pendidikan Karakter dan Pembelajaran Abad 21. SIPATAHOENAN: South-East Asian Journal for Youth, Sports and Health Education, 4(1)1: 17-26.

Mitasari, Z. \& N. A. Prasetiyo. 2016. Penerapan Metode Diskusi-Presentasi Dipadu Analisis Kritis Artikel Melalui Lesson Study untuk Mmeningkatkan Pemahaman Konsep, Kemampuan Berpikir Kritis, dan Komunikasi. Jurnal BIOEDUKATIKA, 4(1): 11-14.

Mufida, R. H., S Mahanal, S Zubaidah. 2017. Pengaruh Model Pembelajaran Biologi Reading-Concept Map-Student Team Achievement Division pada Kemampuan Akademik Berbeda terhadap Keterampilan Berpikir Kreatif Siswa Kelas X MIPA SMA. Vol 2. Prosiding Seminar Pendidikan MIPA Pascasarjana UM.

Mustikawati, S. M. E. Susilowati, R. S. Iswari. 2018. Analysis of Students' Knowledge Mastery and Oral Communication Through the Implementation of Think-PairShare Model. Journal of Biology Education, 7(2): 159-166.

Muthi'ah, A., Y Anwar, L M Santoso. 2018. Pengaruh Penerapan Model Pembelajaran Kooperatif Tipe Jigsaw Terhadap Kemampuan Kognitif dan Keterampilan Sosial di Sekolah Mengengah Atas. Jurnal EDUSAINS, 10(1): 58-64.

National Education Association. Preparing 21st Century Students for a Global Society: An Educator's Guide to the "Four Cs". Pages: 1-37.

Novak, J. D \& Canas, J. A. 2008. The Theory Underlying Concepts Maps and How to Construct and Use Them. Technical Report IHMC CmapTools 2006-01 Rev 012008.

Nurnawati, E., D Yulianti, H Susanto. 2012. Peningkatan Kerjasama Siswa SMP Melalui Penerapan Pembelajaran Kooperatif Pendekatan Think Pair Share. Unnes Physics Education Journal, 1(1): 1-7.

P21 (Partnership for 21st Century Learning). 2007. Framework for 21st Century Learning. Washington DC: Partnership for 21st Century Skills.

Pangestuti, Ardian Anjar. Penerapan Model Pembelajaran Biologi Berbasisi Remap STAD untuk Meningkatkan Kemampuan Berpikir Kritis dan Hasil Belajar Kognitif Mahasiswa IKIP Budi Utomo Malang. Jurnal EDUBIOTIK, 2(1): 1322. 
Pranyandari, N. M., I G A O Negara, I W R Suardika. 2014. Pengaruh Model Pembelajaran Talking Stick Berbasis Concept Mapping Terhadap Hasil Belajar IPA Siswa Kelas V Sekolah Dasar Gugus IV Kuta Utara Tahun Ajaran 2013/2014. Jurnal Mimbar PGSD Universitas Pendidikan Ganesha, 2(1).

Purwaningsih, I., S Mahanal, T I Prasetyo, S Zubaidah. 2017. Pengaruh Model Pembelajara Biologi Reading-Concept Map-Numbered Heads Together dan Gender Terhadap Keterampilan Berpikir Kritis Siswa Kelas X SMAN 10 Malang. Prosiding Senimar Pendidikan IPA Pascasarjana UM. Vol. 2.

Purwatiningsih, Siti. 2009. Penigkatan Prestasi Belajar Biologi Siswa Kelas X.1 SMA N 2 Salatiga Melalui Metode Proyek dengan Penilaian Presentasi dan Poster. Lembaran Ilmu Pendidikan, Jilid 38 (1): 40-52.

Ramadhan, F., S. Mahanal, S. Zubaidah. 2016. Potensi Remap STAD (Reading Concept Mapping Student Teams Achievement Division) untuk Meningkatkan Keterampilan Berpikir Kritis Siswa. Proceeding Biology Education Conference, 13(1): 203-208.

Ratnawati, L., S. Zubaidah, A. D. Corebima. 2015. Pengaruh Model Pembelajaran Biologi berbasis Reading-Concept Map-Jigsaw terhadap Minat Baca dan Hasil Belajar Kognitif Siswa Kelas X SMA Malang. Symbion Jurnal (Symposium on Biology Education). Hlm: 158-165.

Rusman. 2013. Model-model Pembelajaran: Mengembangkan Profesionalisme Guru. Jakarta: Rajawali Pers.

Slavin, Robert E. 2010. Cooperative Learning: Teori, Riset, dan Praktik (terjemahan). Bandung: Nusa Media.

Sukaedi. 2016. Peningkatan Prestasi Belajar Pendidikan Kewarganegaraan Dengan Metode Presentasi dan Diskusi Kelompok (Siswa Kelas III SDN Candijati Arjasa). Jurnal Pancaran, 5(4): 21-30.

Suratno. 2010. Memberdayakan Keterampilan Metakognisi Siswa Dengan Strategi Pembelajaran Jigsaw-Reciprocal Teaching (JIRAT). Jurnal Ilmu Pendidikan, 17(2): 150-156.

Susanto, R. D. dan L. H. Susarno. 2014. Evaluasi Implementasi Model Pembelajaran Kooperatif Tipe Jigsaw Untuk Mata Pelajaran Biologi Pada Kelas XI MIPA di SMA Negeri 1 Jombang, 1(1): 1-9.

Tendrita, M., S. Mahanal, S. Zubaidah. 2016. Pemberdayaan Keterampilan Berpikir Kreatif melalui Model Remap Think Pair Share. Proceeding Biology Education Conference, 13(1):285-291.

Trilling B. \& C. Fadel. 2009. 21 st Century Skills (Learning For Life in Our Times). San Francisco: Jossey-Bass A Wilwy Imprint.

University of Baltimore. Assessment Rubrics for Communication: Oral Communication Skills yang tersedia di http://www.ubalt.edu/merrick/studentresources/rubrics.cfm

Wang, Amber Yayin. 2012. Exploring the Relationship of Creative Thinking to Reading and Writing. Thinking Skill and Creativity, 7: 38-47.

Zubaidah, S., Duran Corebima A., S. Mahanal. 2018. Revealing the Relationship Between Reading Interest and Critical Thinking Skills Through Remap GI and Remap Jigsaw. International Journal of Instruction, 11(2): 41-56.

Zubaidah, Siti. 2014. Pemberdayaan Keterampilan Penemuan Dalam Scientific Approach Melalui Pembelajaran Berbasis Remap Coople. Prosiding Seminar Nasional XI Pendidikan Biologi FKIP UNS. 